\title{
First Morning Voided Urinary Gonadotropin Measurements as an Alternative to the GnRH Test
}

\author{
And Demir $^{a}$ Raimo Voutilainen ${ }^{c}$ Ulf-Håkan Stenman ${ }^{b}$ Leo Dunkel ${ }^{d}$ \\ Kerstin Albertsson-Wikland ${ }^{e, f}$ Ensio Norjavaara ${ }^{e, f}$ \\ ${ }^{a}$ Children's Hospital and bepartment of Clinical Chemistry, Helsinki University Central Hospital, Helsinki, and \\ 'Department of Pediatrics, Kuopio University Hospital and University of Eastern Finland, Kuopio, Finland; \\ dWilliam Harvey Research Institute, Barts and the London, Queen Mary University of London, London, UK; \\ e Department of Pediatrics, Institute of Clinical Sciences, Gothenburg Pediatric Growth Research Center, and \\ fSahlgrenska Academy, University of Gothenburg, Gothenburg, Sweden
}

\section{Key Words}

Luteinizing hormone · Follicle-stimulating hormone ·

Gonadotropin-releasing hormone test .

Hypothalamic-pituitary-gonadal function · Pubertal disorders

\begin{abstract}
Aims: We studied whether first morning voided (FMV) urinary gonadotropin measurements could be used as a noninvasive alternative to the $\mathrm{GnRH}$ test in the assessment of the hypothalamic-pituitary-gonadal function in children. Methods: In a single-center study, we compared FMV urinary gonadotropin concentrations with basal and GnRH-stimulated serum gonadotropin levels in 274 children and adolescents (78 girls, 196 boys) aged 5-17 years referred for growth and pubertal disorders. The concordance between FMV urinary gonadotropin concentrations and $\mathrm{GnRH}$ test results was assessed. Results: FMV urinary LH (U-LH), urinary FSH (U-FSH) and their ratios correlated well with the corresponding basal and GnRH-stimulated serum parameters $(r \geq 0.66, p<0.001)$. Receiver operating characteristic curve analyses using urinary and serum $\mathrm{LH}$ and FSH concentrations showed that FMV U-LH and U-LH/U-FSH performed equally well as the $\mathrm{GnRH}$ test in the differentiation of early puberty (Tanner
\end{abstract}

stage 2) from prepuberty (Tanner stage 1) (area under the curve $0.768-0.890$ vs. $0.712-0.858$ ). FMV U-LH and U-LH/UFSH performed equally well as basal serum $\mathrm{LH}$ in predicting a pubertal GnRH test result (area under the curve 0.90-0.93). Conclusion: FMV U-LH determination can be used for the evaluation of pubertal development and its disorders, reducing the need for invasive GnRH stimulation tests.

(c) 2016 S. Karger AG, Basel

\section{Introduction}

The onset of pubertal maturation is heralded by increased nighttime secretion of gonadotropins, which is characterized by stronger bursts of LH than FSH secretion. Basal serum LH (S-LH) concentrations reflect the course of pubertal development better than serum FSH (S-FSH) levels, as they increase about 50- to 100 -fold between prepuberty and adulthood, while the corresponding increase in S-FSH is about 10 -fold $[1,2]$. For more than 40 years, the $\mathrm{GnRH}$ test has been considered the reference method for assessing the hypothalamic-pituitarygonadal (HPG) axis function in pubertal disorders $[3,4]$, because the previously used radioimmunoassay methods

\section{KARGER}

E-Mail karger@karger.com

www.karger.com/hrp
(C) 2016 S. Karger AG, Basel

$1663-2818 / 16 / 0855-0301 \$ 39.50 / 0$
And Demir, MD, PhD, MBA

Children's Hospital

Stenbäckinkatu 11

FI-00029 HUS Helsinki (Finland)

E-Maildrand@demir.net 
did not accurately measure the low basal S-LH and S-FSH levels in prepubertal children. The GnRH test appears to be a better tool for the evaluation of sexual precocity than for delayed puberty [5-10].

Major drawbacks of the GnRH stimulation test are its invasive nature, requirements for adequate hospital facilities and personnel for the test as well as the cost for several S-FSH and S-LH measurements. There have been many attempts to simplify this test, e.g. by determining LH concentration only in a single blood sample obtained at a selected time point [10-12]. As timed urinary gonadotropin excretion reflects integrated gonadotropin secretion, its measurement provides an alternative approach for assessing the function of the HPG axis. Indeed, our previous studies showed that the pubertal developmental stage evaluated by physical examination correlates well with first morning voided (FMV) urinary gonadotropin concentrations [13]. Maesaka et al. [14] have demonstrated that the patterns of monthly urinary gonadotropin excretion in patients with idiopathic precocious puberty are comparable to those in normal subjects matched for pubertal stage.

When determined by a highly sensitive assay, baseline S-LH measurement has been shown to be a sensitive method for the detection of early puberty $[1,15]$. Similar findings were recently reported by Pasternak et al. [16], who suggested that basal S-LH concentrations can be used for the evaluation of girls with clinically suspected central precocious puberty. Resende et al. [17] argued, on the basis of their data obtained by immunochemiluminometric assay that boys are unlikely to require a $\mathrm{GnRH}$ test to differentiate the pubertal and prepubertal stage, because basal S-LH alone measured by immunochemiluminometric assay was capable of distinguishing these stages. Previous studies have revealed a good correlation between basal S-LH and FMV urinary LH (U-LH) concentrations $[13,18]$ as well as a clear increase in FMV U-LH concentrations and U-LH/urinary FSH (U-FSH) ratios at the start of puberty $[13,19]$. Furthermore, FMV U-LH levels reflect the nocturnal increase in $\mathrm{LH}$ secretion and indicate the imminent onset of puberty earlier than daytime S-LH concentrations [13].

The aim of this study was to analyze how well FMV urinary gonadotropin concentration measurements agree with the GnRH stimulation test result, which is the current gold standard for the evaluation of pubertal disorders, and how well they predict the transition from prepuberty to puberty in girls and boys based on clinical, i.e. Tanner, staging.

\section{Methods}

Subjects

FMV urinary as well as serum samples (in conjunction with the same-day GnRH stimulation test) were collected from 274 children and adolescents (78 girls, 196 boys) aged 5-17 years (girls: 6.4-17.4 years; boys: $5.2-17.7$ years) with clinically evaluated pubertal stage determined at the Gothenburg Pediatric Growth Research Center (GP-GRC) during a 3.5-year period. Tanner breast stage $(\mathrm{B}) \geq 2$ or a testicular volume $>3 \mathrm{ml}$ were taken as a definite sign of puberty [20]. The subjects had been referred to the GPGRC for investigation of growth or pubertal disorders (mainly short or tall stature and suspected precocious or delayed puberty). The GnRH stimulation test was not used to classify these patients.

\section{Urinary Samples}

Samples from menstruating girls were taken outside their menstrual periods. The subjects emptied their bladders just before bedtime. The entire nighttime (FMV) urine was collected and an aliquot was used for gonadotropin analyses performed within 1-7 days.

\section{GnRH Test}

After an overnight fast, GnRH $(3.5 \mu \mathrm{g} / \mathrm{kg}$, maximum $100 \mu \mathrm{g}$; Relefact, Hoechst AG, Frankfurt, Germany) was injected as an intravenous bolus through an indwelling catheter. Two milliliters of blood were collected immediately before injection ( 0 -min sample) and then 30, 60 and 90 min after the injection. Serum was separated by centrifugation.

\section{Gonadotropin Assays}

Urinary and serum LH and FSH were determined by time-resolved sandwich fluoroimmunoassays, as previously described [21]. The assay kits were used as recommended by the manufacturer (Delfia hLH Spec and Delfia hFSH; Wallac Oy, Turku, Finland). The assays were calibrated against the WHO Second International Standard for pituitary LH for immunoassay (80/552) and the Second International Reference Preparation of Pituitary FSH/ LH (78/549), respectively. The detection limits for S-LH and SFSH were 0.02 and $0.035 \mathrm{IU} / \mathrm{l}$, respectively, and the intra-assay coefficients of variation for both assays were $<2 \%$ at levels between 3 and $250 \mathrm{IU} / \mathrm{l}$ and about $10 \%$ at $0.3 \mathrm{IU} / \mathrm{l}$. The inter-assay coefficient of variation was $<3 \%$ at $4-18$ IU/l for both FSH and LH [22]. The detection limit of the U-FSH assay was $0.018 \mathrm{IU} / 1$ and that of the U-LH assay was $0.015 \mathrm{IU} / \mathrm{l}$. The intra- and inter-assay coefficients of variation for the U-FSH and U-LH assays ranged between 2.3 and $7.8 \%$ and between 5.2 and $8.7 \%$, respectively [18]. Hormone concentrations were not corrected for variations in urine excretion rate (such as urinary density or creatinine) because the correlation with serum levels was not improved but even impaired due to overcorrection in very dilute urine samples. The LH and FSH assays were further validated by showing that the urine matrix did not affect the results and that urine could be stored for up to 7 weeks at $+4^{\circ} \mathrm{C}$ without a significant loss of LH and FSH [18].

\section{Statistical Analyses}

According to the clinical practice at the GP-GRC, the GnRH stimulation test result was classified as pubertal if the maximum S-LH concentration $\left(\mathrm{S}-\mathrm{LH}_{\max }\right)$ was $>5.0 \mathrm{IU} / \mathrm{l}$ and the $\mathrm{S}-\mathrm{LH}_{\max }$ / $\mathrm{S}-\mathrm{FSH}_{\max }$ ratio $>1.0$. For statistical evaluation, FSH and LH concentrations below the detection limit were assigned a value of $0.01 \mathrm{IU} / \mathrm{l}$.
Demir/Voutilainen/Stenman/Dunkel/

Albertsson-Wikland/Norjavaara 
Table 1. Correlation between FMV urinary gonadotropin concentrations and their ratios with the respective $\mathrm{S}-\mathrm{LH}_{\max }$ and $\mathrm{S}$-FSH $\mathrm{H}_{\max }$ values in $\mathrm{GnRH}$ stimulation tests, as well as correlations of these values with the clinically determined pubertal stage

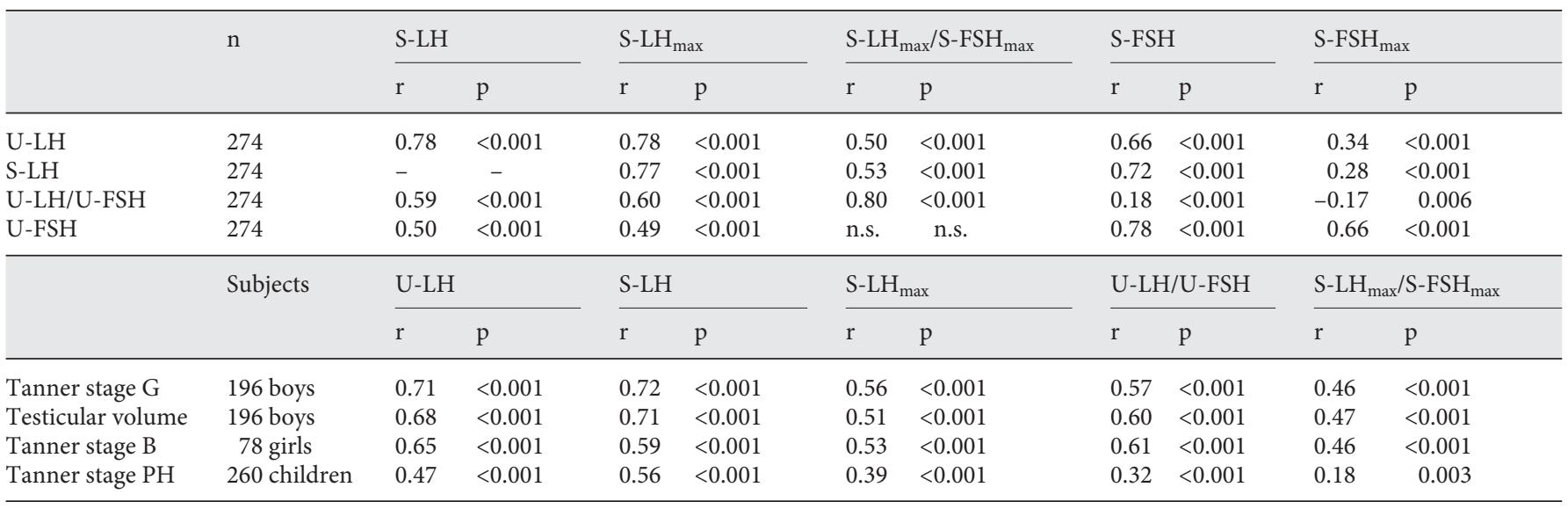

n.s. $=$ Not significant

We analyzed the correlation between gonadotropin concentrations and their ratios in FMV urine (U-FSH, U-LH, U-LH/ $\mathrm{U}-\mathrm{FSH}$ ) and serum during the GnRH stimulation test (basal FSH = $\mathrm{S}-\mathrm{FSH}$, basal LH $=\mathrm{S}-\mathrm{LH}, \mathrm{FSH}_{\max }=\mathrm{S}-\mathrm{FSH}_{\max }, \mathrm{LH}_{\max }=\mathrm{S}-\mathrm{LH}_{\max }$, $\left.\mathrm{S}-\mathrm{LH}_{\max } / \mathrm{S}-\mathrm{FSH}_{\max }\right)$ using regression and correlation analyses (Spearman's test). Furthermore, the correlations between the pubertal stages [Tanner breast stage (B), genital stage $(G)$, pubic hair stage $(\mathrm{PH})$, testicular volume] and gonadotropin concentrations were determined.

The diagnostic validity of various tests was evaluated by receiver operating characteristic (ROC) curve analysis [23] to calculate the area under the curve (AUC), sensitivity and specificity levels at various cut-off values for the differentiation of early pubertal (Tanner stage B/G 2) from prepubertal (Tanner stage B/G 1), and separately to predict the pubertal response in the $\mathrm{GnRH}$ stimulation test. Differences in the median gonadotropin concentrations between pubertal stages in both sexes were analyzed by the nonparametric Kruskal-Wallis test for a general overview and subsequently by the Mann-Whitney $U$ test for adjacent pubertal stages. A p value $<0.05$ was considered statistically significant.

\section{Statement of Ethics}

The research protocol was approved by the Ethics Committee at Sahlgrenska University Hospital, University of Gothenburg. Informed consent was obtained from the parents.

\section{Results}

The FMV U-LH and U-FSH concentrations correlated well with the corresponding basal and GnRH-stimulated serum levels $(\mathrm{r} \geq 0.66, \mathrm{p}<0.001$ for all), and there was also a very strong correlation between the FMV U-LH/ $\mathrm{U}-\mathrm{FSH}$ and $\mathrm{S}-\mathrm{LH}_{\max } / \mathrm{S}-\mathrm{FSH}_{\max }$ ratios $(\mathrm{r}=0.80, \mathrm{p}<0.001)$

First Morning Voided Urinary LH in the Evaluation of Pubertal Disorders (table 1). The correlations were similar in the subgroups of prepubertal and pubertal subjects (data not shown). The correlation of U-LH and S-LH with pubertal stage (Tanner stage $\mathrm{B} / \mathrm{G}$ ) and testicular volume was also strong $(\mathrm{r} \geq 0.59, \mathrm{p}<0.001$ for all) (table 1$)$.

Table 2 depicts the medians and ranges of FMV U$\mathrm{LH}, \mathrm{U}-\mathrm{FSH}, \mathrm{S}-\mathrm{LH}$ and S- $\mathrm{LH}_{\max }$ concentrations as well as FMV U-LH/U-FSH and $\mathrm{S}-\mathrm{LH}_{\max } / \mathrm{S}-\mathrm{FSH}_{\max }$ ratios according to the Tanner pubertal stages, separately in boys and girls (see fig. 1 for the pattern of distribution of the values). The table shows that the increase in FMV U-LH and U-LH/U-FSH ratios between prepuberty (Tanner stage $B / G 1$ ) and the earliest pubertal stage (Tanner stage $B / G$ 2) was equally or more significant compared to the respective increase in $\mathrm{S}-\mathrm{LH}$ or $\mathrm{S}-\mathrm{LH}_{\max }$ concentrations and $\mathrm{S}-\mathrm{LH}_{\max } / \mathrm{S}-\mathrm{FSH}_{\max }$ ratios, respectively.

The ability of various tests to classify subjects as being clinically prepubertal or pubertal was compared using ROC curve analysis. The U-LH concentrations and U$\mathrm{LH} / \mathrm{U}-\mathrm{FSH}$ ratios turned out to be at least as good as the S-LH and S- $\mathrm{LH}_{\max }$ concentrations or the S-LH/S-FSH and $\mathrm{S}-\mathrm{LH}_{\max } / \mathrm{S}-\mathrm{FSH}_{\max }$ ratios to differentiate clinically classified early pubertal from prepubertal children (table 3, upper part). Since S- $\mathrm{LH}_{\max }$ after $\mathrm{GnRH}$ stimulation is considered the gold standard for the evaluation of pubertal state biochemically, we also studied by ROC curve analysis how the U-LH and FSH concentrations performed compared with the GnRH test result. The U-LH concentration and the U-LH/U-FSH ratio performed equally well as the basal S-LH concentration in predicting 


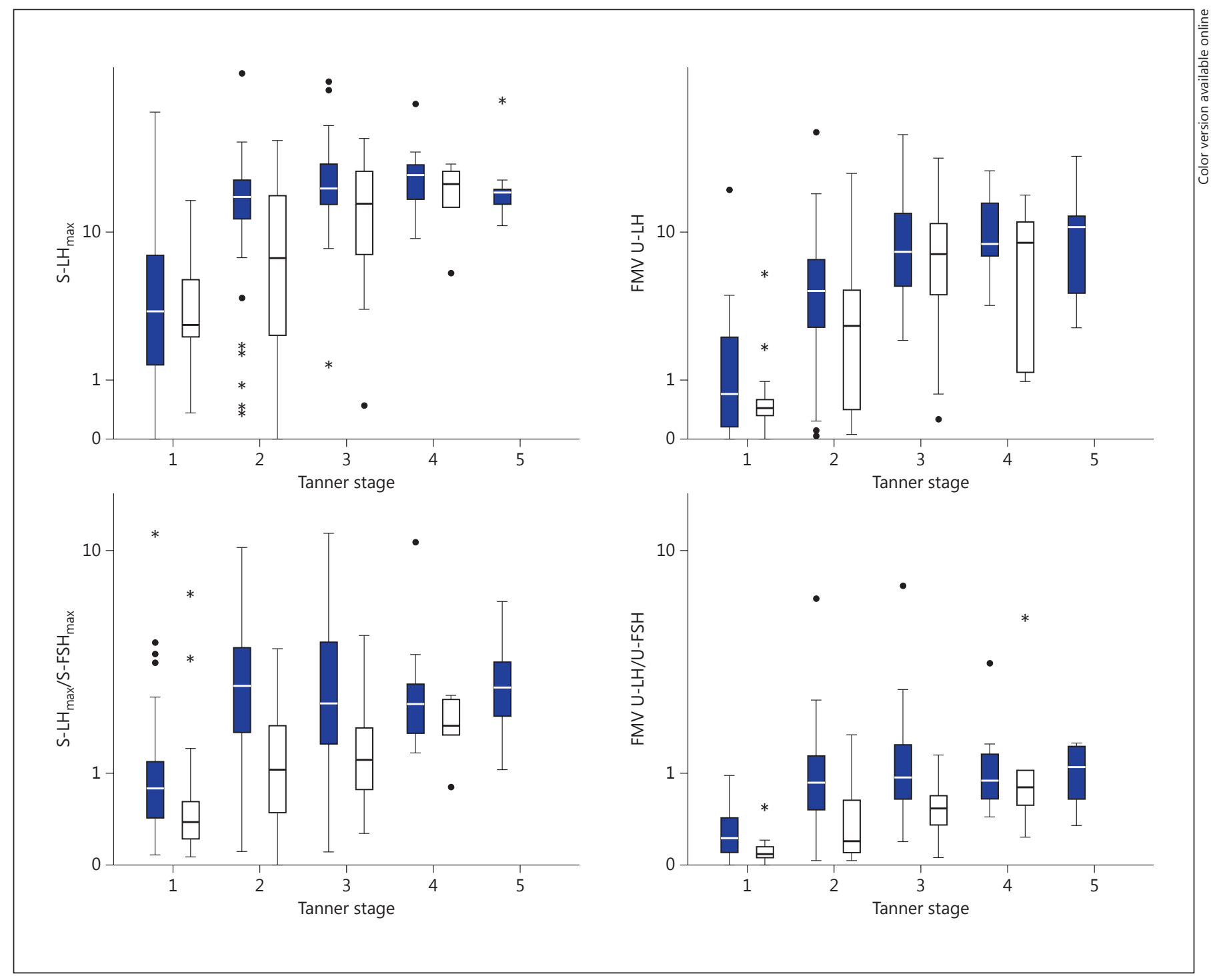

Fig. 1. Distribution of S- $\mathrm{LH}_{\max }$ concentrations (IU/l) compared to FMV U-LH concentrations (IU/l) (upper panels) and that of S$\mathrm{LH}_{\max }$ and $\mathrm{FSH}_{\max }$ concentration ratios in the GnRH test compared to FMV U-LH and U-FSH concentration ratios (lower panels) in different Tanner G/B stages. The filled boxes represent boys and the open ones girls. Note the logarithmic scale of the $y$-axes.
The lines in the boxes represent the median values, the lower and upper limits of the boxes correspond to the 25th and 75th percentiles, and the whiskers represent the $95 \%$ confidence interval limits. Outliers are plotted separately. Mild and extreme outliers are marked with a circle or asterisk, respectively. the pubertal GnRH test result (AUC about 0.9 for all) (table 3, lower part).

Among boys with Tanner stages 1-2, the sensitivity to detect puberty with the GnRH test was $92 \%$ at a specificity of $66 \%$ (table 4 ). The same sensitivity was obtained with a cut-off value of $1.48 \mathrm{IU} / \mathrm{l}$ for $\mathrm{U}-\mathrm{LH}$ and of $0.05 \mathrm{IU} / 1$ for S-LH with an equal specificity of $67 \%$ for both methods. Among girls at Tanner stages 1-2, the sensitivity of the GnRH test to detect puberty was only $59 \%$ and the specificity $66 \%$. For the same level of sensitivity (59\%), it was possible to obtain a specificity of $96 \%$ for U-LH and of $69 \%$ for S-LH at cut-off levels of 2.60 and $0.03 \mathrm{IU} / 1$, respectively (table 4 ). Cut-off values of $1.5 \mathrm{IU} / \mathrm{l}$ for U-LH in boys and of $1.2 \mathrm{IU} / \mathrm{l}$ in girls pro- 
Table 2. FMV U-LH and U-FSH concentrations (IU/l) and their ratios, and S-LH and S- $\mathrm{LH}_{\max }$ concentrations (IU/l) as well as S-LH $\mathrm{Lax}_{\max }$ and $\mathrm{S}-\mathrm{FSH}_{\max }$ concentration ratios in the $\mathrm{GnRH}$ test

\begin{tabular}{|c|c|c|c|c|c|c|c|c|c|}
\hline Boys & $\mathrm{G} 1(\mathrm{n}=61)$ & $\mathrm{p}$ & $\mathrm{G} 2(\mathrm{n}=77)$ & $\mathrm{p}$ & $\mathrm{G} 3(\mathrm{n}=29)$ & $\mathrm{p}$ & $\mathrm{G} 4(\mathrm{n}=19)$ & $\mathrm{p}$ & $\mathrm{G} 5(\mathrm{n}=10)$ \\
\hline U-LH/U-FSH & $\begin{array}{l}0.22 \\
(0.01-0.98)\end{array}$ & $*$ & $\begin{array}{l}0.86 \\
(0.03-6.65)\end{array}$ & n.s. & $\begin{array}{l}0.94 \\
(0.19-7.45)\end{array}$ & n.s. & $\begin{array}{l}0.89 \\
(0.45-3.66)\end{array}$ & n.s. & $\begin{array}{l}1.10 \\
(0.34-1.54)\end{array}$ \\
\hline S-LH & $\begin{array}{l}0.03 \\
(0.01-0.98)\end{array}$ & $*$ & $\begin{array}{l}0.18 \\
(0.01-4.30)\end{array}$ & $* *$ & $\begin{array}{l}0.26 \\
(0.08-2.80)\end{array}$ & $* * *$ & $\begin{array}{l}0.40 \\
(0.12-0.75)\end{array}$ & n.s. & $\begin{array}{l}0.43 \\
(0.12-0.75)\end{array}$ \\
\hline $\mathrm{S}-\mathrm{LH}_{\max } / \mathrm{S}-\mathrm{FSH}_{\max }$ & $\begin{array}{l}0.78 \\
(0.07-11.62)\end{array}$ & $*$ & $\begin{array}{l}2.89 \\
(0.10-10.34)\end{array}$ & n.s. & $\begin{array}{l}2.43 \\
(0.10-11.60)\end{array}$ & n.s. & $\begin{array}{l}2.39 \\
(1.35-10.80)\end{array}$ & n.s. & $\begin{array}{l}2.88 \\
(1.07-6.50)\end{array}$ \\
\hline Girls & $\mathrm{B} 1(\mathrm{n}=24)$ & $\mathrm{p}$ & $\mathrm{B} 2(\mathrm{n}=28)$ & $\mathrm{p}$ & $\mathrm{B} 3(\mathrm{n}=20)$ & $\mathrm{p}$ & $\mathrm{B} 4(\mathrm{n}=6)$ & & \\
\hline S-LH & $\begin{array}{l}0.02 \\
(0.01-0.70)\end{array}$ & $* * *$ & $\begin{array}{l}0.07 \\
(0.01-1.15)\end{array}$ & $* * *$ & $\begin{array}{l}0.24 \\
(0.03-0.93)\end{array}$ & n.s. & $\begin{array}{l}0.45 \\
(0.18-0.85)\end{array}$ & & \\
\hline $\mathrm{S}-\mathrm{LH}_{\max }$ & $\begin{array}{l}2.30 \\
(0.30-12.50)\end{array}$ & $* * *$ & $\begin{array}{l}5.98 \\
(0.01-26.00)\end{array}$ & n.s. & $\begin{array}{l}12.00 \\
(0.40-26.50)\end{array}$ & n.s. & $\begin{array}{l}15.25 \\
(4.90-19.50)\end{array}$ & & \\
\hline S-LH $\mathrm{Lmax}_{\operatorname{m}} / \mathrm{S}-\mathrm{FSH}_{\max }$ & $\begin{array}{l}0.38 \\
(0.07-6.94)\end{array}$ & $* *$ & $\begin{array}{l}1.05 \\
(0.01-4.24)\end{array}$ & n.s. & $\begin{array}{l}1.21 \\
(0.27-4.77)\end{array}$ & n.s. & $\begin{array}{l}1.88 \\
(0.81-2.65)\end{array}$ & & \\
\hline
\end{tabular}

Figures are medians (ranges). 274 children and adolescents with designated Tanner stages are listed. The differences in hormone concentrations or their ratios between adjacent pubertal stages were analyzed by the nonparametric Kruskal-Wallis and Mann-Whitney U tests. G1-G5 = Tanner genital stages $1-5$ in boys; B1-B4 = Tanner breast stages $1-4$ in girls; n.s. = not significant.

${ }^{*} \mathrm{p}<0.001 ; * \mathrm{p}<0.01 ;{ }^{* * *} \mathrm{p}<0.05$.

vided optimal sensitivity and specificity for identification of puberty. The corresponding cut-off values for S-LH would be $0.04 \mathrm{IU} / \mathrm{l}$ for boys and $0.02 \mathrm{IU} / \mathrm{l}$ for girls (table 4).

\section{Discussion}

The FMV U-LH concentrations correlated well with the basal S-LH levels, agreeing with previous studies in children and adolescents without endocrine disorders $[13,18,24]$. FMV U-LH also correlated very well with S$\mathrm{LH}_{\max }$ and so did the FMV U-LH/U-FSH ratio with the $\mathrm{S}-\mathrm{LH}_{\max } / \mathrm{S}-\mathrm{FSH}_{\max }$ ratio. This is in line with previous studies on girls with precocious puberty: Witchel et al. [25] found a good correlation between 24-h U-LH and S$\mathrm{LH}_{\max }$ in 18 girls on $\mathrm{GnRH}$ analog treatment, and Zung et al. [26] between FMV U-LH and S- $\mathrm{LH}_{\max }$ and the S-
$\mathrm{LH}_{\max } / \mathrm{S}-\mathrm{FSH}_{\max }$ ratio in 47 girls with signs of precocious puberty. On the basis of the excellent correlations between the FMV U-LH and S- $\mathrm{LH}_{\max }$ concentrations in this study, it is not surprising that the FMV U-LH concentrations and U-LH/U-FSH ratios correlated at least equally well as $\mathrm{S}-\mathrm{LH}_{\max }$ and the $\mathrm{S}-\mathrm{LH}_{\max } / \mathrm{S}-\mathrm{FSH}_{\max }$ ratios with the pubertal developmental stage (slightly higher $r$ values for the urine tests).

Both FMV U-LH and S- $\mathrm{LH}_{\max }$ as well as the U-LH/UFSH and S- $\mathrm{LH}_{\max } / \mathrm{S}-\mathrm{FSH}_{\max }$ ratios increased significantly between the prepubertal and early pubertal stage in both sexes (G1 vs. G2 and B1 vs. B2), but there was a significant overlap in all these values between these pubertal stages. Our current results are in accordance with those from earlier studies in healthy children $[13,19]$ and partly with those of McNeilly et al. [27], who found significant differences in U-LH concentrations and U-LH/U-FSH ratios between prepubertal and pubertal children. 
Table 3. Area under the ROC curve for urinary and serum LH, FSH and $\mathrm{GnRH}$ test variables to differentiate Tanner stage (G/B) 2 from stage 1 (upper part), and AUC for U-LH/FSH, U-LH, U-FSH and $\mathrm{S}$-LH to predict a pubertal GnRH test result among the prepubertal (Tanner stage 1) and early pubertal (Tanner stage 2) children (lower part)

\begin{tabular}{|c|c|c|c|}
\hline & \multirow[t]{2}{*}{ AUC } & \multicolumn{2}{|c|}{$\begin{array}{l}\text { AUC vs. Tanner stage 2, } \\
95 \% \text { CI }\end{array}$} \\
\hline & & lower & upper \\
\hline \multicolumn{4}{|c|}{ Boys $(\mathrm{G} 1$ and $\mathrm{G} 2, \mathrm{n}=138)$} \\
\hline U-LH/U-FSH & 0.890 & 0.836 & 0.945 \\
\hline U-LH & 0.863 & 0.800 & 0.926 \\
\hline S-LH & 0.863 & 0.794 & 0.931 \\
\hline S- $\mathrm{LH}_{\max } / \mathrm{S}-\mathrm{FSH}_{\max }$ & 0.858 & 0.786 & 0.930 \\
\hline $\mathrm{S}-\mathrm{LH}_{\max }$ & 0.822 & 0.741 & 0.904 \\
\hline S-LH/S-FSH & 0.779 & 0.697 & 0.860 \\
\hline U-FSH & 0.651 & 0.558 & 0.744 \\
\hline \multicolumn{4}{|l|}{ Girls $(\mathrm{B} 1$ and $\mathrm{B} 2, \mathrm{n}=52)$} \\
\hline U-LH & 0.791 & 0.652 & 0.930 \\
\hline U-LH/U-FSH & 0.768 & 0.635 & 0.900 \\
\hline $\mathrm{S}-\mathrm{LH}_{\max } / \mathrm{S}-\mathrm{FSH}_{\max }$ & 0.736 & 0.592 & 0.881 \\
\hline $\mathrm{S}-\mathrm{LH}_{\max }$ & 0.712 & 0.561 & 0.862 \\
\hline U-FSH & 0.687 & 0.531 & 0.842 \\
\hline S-LH & 0.673 & 0.522 & 0.824 \\
\hline \multirow[t]{3}{*}{ S-LH/S-FSH } & 0.671 & 0.515 & 0.826 \\
\hline & AUC & \multicolumn{2}{|c|}{$\begin{array}{l}\text { AUC vs. pubertal GnRH } \\
\text { test positive, } 95 \% \mathrm{CI}\end{array}$} \\
\hline & & lower & upper \\
\hline \multicolumn{4}{|c|}{ Boys (G1 and G2, $\mathrm{n}=138$ ) } \\
\hline U-LH/U-FSH & 0.925 & 0.869 & 0.981 \\
\hline U-LH & 0.902 & 0.836 & 0.967 \\
\hline U-FSH & 0.747 & 0.664 & 0.829 \\
\hline S-LH & 0.929 & 0.874 & 0.984 \\
\hline \multicolumn{4}{|c|}{ Girls $(\mathrm{B} 1$ and $\mathrm{B} 2, \mathrm{n}=52)$} \\
\hline U-LH/U-FSH & 0.911 & 0.869 & 0.953 \\
\hline U-LH & 0.880 & 0.830 & 0.929 \\
\hline U-FSH & 0.662 & 0.593 & 0.730 \\
\hline S-LH & 0.898 & 0.854 & 0.943 \\
\hline
\end{tabular}

In ROC curve analyses, the AUC values of FMV U-LH and U-LH/U-FSH for predicting clinically established puberty (Tanner stage $B / G 2$ ) were actually slightly better than those of the GnRH stimulation test parameters, especially in girls. Among girls, the sensitivity of the $\mathrm{GnRH}$ test to detect clinical puberty was rather low (59\%) with the criteria used in this study. The U-LH concentration
Table 4. Different cut-off values for FMV U-LH, FMV U-LH/UFSH and S-LH in their ability to predict started puberty (Tanner G/B stage 2) on the basis of sexual maturation rating (upper part) or pubertal GnRH test result (lower part) among the prepubertal (Tanner G/B stage 1 ) and early pubertal (Tanner G/B stage 2 ) children

\begin{tabular}{|c|c|c|c|}
\hline & $\begin{array}{l}\text { Cut-off } \\
\text { value }^{\mathrm{a}}\end{array}$ & $\begin{array}{l}\text { Sensi- } \\
\text { tivity }\end{array}$ & $\begin{array}{l}\text { Speci- } \\
\text { ficity }\end{array}$ \\
\hline \multicolumn{4}{|c|}{ Boys $(\mathrm{G} 1$ and $\mathrm{G} 2, \mathrm{n}=138)$} \\
\hline GnRH test & & $92.2 \%$ & $65.8 \%$ \\
\hline $\mathrm{S}-\mathrm{LH}_{\max }$ & $\geq 5.00 \mathrm{IU} / 1$ & $92.2 \%$ & $66.7 \%$ \\
\hline S- $\mathrm{LH}_{\max } / \mathrm{S}-\mathrm{FSH}_{\max }$ & $\geq 1.00$ & $92.2 \%$ & $64.9 \%$ \\
\hline \multirow[t]{2}{*}{ FMV U-LH } & $\geq 1.48 \mathrm{IU} / 1$ & $92.2 \%$ & $66.7 \%$ \\
\hline & $\geq 1.44 \mathrm{IU} / 1$ & $92.2 \%$ & $65.8 \%$ \\
\hline \multirow[t]{2}{*}{ FMV U-LH/U-FSH } & $\geq 0.35$ & $92.2 \%$ & $68.4 \%$ \\
\hline & $\geq 0.33$ & $93.5 \%$ & $65.8 \%$ \\
\hline \multirow[t]{2}{*}{ S-LH } & $\geq 0.05 \mathrm{IU} / 1$ & $92.2 \%$ & $66.7 \%$ \\
\hline & $\geq 0.04 \mathrm{IU} / 1$ & $92.9 \%$ & $65.8 \%$ \\
\hline \multicolumn{4}{|l|}{ Girls $(\mathrm{B} 1$ and $\mathrm{B} 2, \mathrm{n}=52)$} \\
\hline GnRH test & & $58.7 \%$ & $65.8 \%$ \\
\hline $\mathrm{S}-\mathrm{LH}_{\max }$ & $\geq 5.00 \mathrm{IU} / 1$ & $53.3 \%$ & $66.7 \%$ \\
\hline $\mathrm{S}-\mathrm{LH}_{\max } / \mathrm{S}-\mathrm{FSH}_{\max }$ & $\geq 1.00$ & $64.1 \%$ & $64.9 \%$ \\
\hline \multirow[t]{3}{*}{ FMV U-LH } & $\geq 2.60 \mathrm{IU} / 1$ & $58.7 \%$ & $95.8 \%$ \\
\hline & $\geq 2.30 \mathrm{IU} / 1$ & $65.4 \%$ & $95.8 \%$ \\
\hline & $\geq 1.20 \mathrm{IU} / 1$ & $73.1 \%$ & $91.7 \%$ \\
\hline \multirow[t]{3}{*}{ FMV U-LH/U-FSH } & $\geq 0.17$ & $58.7 \%$ & $79.2 \%$ \\
\hline & $\geq 0.17$ & $65.4 \%$ & $79.2 \%$ \\
\hline & $\geq 0.10$ & $73.1 \%$ & $65.8 \%$ \\
\hline \multirow[t]{2}{*}{ S-LH } & $\geq 0.03 \mathrm{IU} / 1$ & $58.7 \%$ & $68.9 \%$ \\
\hline & $\geq 0.02 \mathrm{IU} / 1$ & $66.0 \%$ & $65.8 \%$ \\
\hline \multicolumn{4}{|l|}{ Boys (G1 and G2, $\mathrm{n}=138$ ) } \\
\hline \multirow[t]{4}{*}{ FMV U-LH } & $\geq 0.48 \mathrm{IU} / 1$ & $100.0 \%$ & $60.0 \%$ \\
\hline & $\geq 1.48 \mathrm{IU} / 1$ & $95.1 \%$ & $76.9 \%$ \\
\hline & $\geq 1.75 \mathrm{IU} / 1$ & $91.5 \%$ & $82.7 \%$ \\
\hline & $\geq 3.13 \mathrm{IU} / 1$ & $72.0 \%$ & $91.4 \%$ \\
\hline \multirow[t]{3}{*}{ FMV U-LH/U-FSH } & $\geq 0.33$ & $97.6 \%$ & $78.8 \%$ \\
\hline & $\geq 0.43$ & $87.8 \%$ & $91.4 \%$ \\
\hline & $\geq 0.50$ & $80.5 \%$ & $94.2 \%$ \\
\hline \multicolumn{4}{|l|}{ Girls $(\mathrm{B} 1$ and $\mathrm{B} 2, \mathrm{n}=52)$} \\
\hline \multirow[t]{2}{*}{ FMV U-LH } & $\geq 1.20 \mathrm{IU} / 1$ & $80.0 \%$ & $74.0 \%$ \\
\hline & $\geq 2.50 \mathrm{IU} / 1$ & $66.7 \%$ & $80.0 \%$ \\
\hline \multirow[t]{2}{*}{ FMV U-LH/U-FSH } & $\geq 0.14$ & $80.0 \%$ & $65.7 \%$ \\
\hline & $\geq 0.20$ & $60.0 \%$ & $80.0 \%$ \\
\hline
\end{tabular}

${ }^{a}$ Upper part: versus Tanner stage 2; lower part: versus pubertal $\mathrm{GnRH}$ test result.

and the U-LH/U-FSH ratio gave higher specificity (96 and $79 \%$, respectively) than the GnRH test (66\%) at this sensitivity level.

Increasing FMV U-LH excretion is an early indicator of HPG axis activation. A substantial portion of the boys and some of the girls classified as prepubertal by Tanner staging showed evidence of biochemical pubertal activa- 
tion on the basis of the FMV U-LH concentration. This is in accordance with previous reports showing activation of the HPG axis before clinical manifestations of puberty $[13,24,28]$. FMV U-LH measurements have been shown to detect an increase in LH secretion 1-2 years before the onset of physical puberty as well as before the rise in morning S-LH concentrations [13].

The fairly high rate of apparently 'false-negative' U-LH and $\mathrm{GnRH}$ test results especially in girls could possibly be caused by errors in Tanner staging or by breast development initiated by other endocrine factors than gonadotropin-induced ovarian estrogens. Indeed, even when pubertal staging is performed by an experienced pediatric endocrinologist, Tanner staging is more subjective in girls than in boys. In general, U-LH measurements worked well in the evaluation of pubertal development compared with the GnRH test. With the current cut-off values, the GnRH test appears to be reliable for identification of clinical puberty in boys but not in girls. This sex difference (low sensitivity in girls) is probably at least partly explained by 'false' Tanner breast stage classification in girls, i.e. interpretation of thelarche as a definite sign of puberty. It is also of note that the cut-off values of the GnRH test used here for a pubertal response were quite demanding (see discussion in [26]). Girls may need a slightly lower $\mathrm{S}-\mathrm{LH}_{\max }$ cut-off value than boys in the GnRH test. This view is indirectly also supported by the slightly lower cut-off values for U-LH in girls than boys derived from the ROC curve analyses in the present study.

Basal S-LH measurements alone are also suitable for evaluating pubertal development if blood is to be drawn for other reasons. However, the current study indicates that neither boys nor girls require S-LH measurements or $\mathrm{GnRH}$ tests for the initial evaluation of pubertal development. Furthermore, S-LH results in children are reliable only if the assay is sensitive enough to measure the concentrations around the cut-off values in the range $0.02-$ $0.05 \mathrm{IU} / \mathrm{l}$. On the basis of the somewhat higher U-LH than S-LH concentrations, a single measurement of LH in FMV urine provides reliable information about pubertal hormonal development, and it is comparable to that obtained by measuring S-LH or performing the GnRH stimulation test.

When starting to test the utility of urinary gonadotropin measurements in the evaluation of pubertal HPG axis function in early 1990s, we chose FMV urinary samples because they had mostly been used and supposed to best reflect nighttime gonadotropin secretion pulses typical for early puberty $[14,29,30]$. However, Bourguignon et al. [31] had earlier reported that urine samples collected between 8 and 12 a.m. contained somewhat unexpectedly more LH and FSH than samples collected between midnight and 4 a.m. and samples collected between 4 a.m. and 8 a.m. Thus, additional detailed studies comparing U-FSH and U-LH concentrations in first and second morning voided urinary samples from the same subjects with different pubertal stages would be well-grounded.

A potential limitation of FMV U-LH assays is the fact that a large part of LH immunoreactivity in urine consist of a fragment of the $\mathrm{LH} \beta$ subunit called the core fragment (LH $\beta \mathrm{cf}$ ) [32]. Different assays recognize this fragment to variable degrees, and therefore the measured LH concentrations are highly dependent on the assay used [33]. There are also differences in the detection limits for $\mathrm{LH}$, and a reliable estimation of low prepubertal levels requires the use of a highly sensitive assay. The stability of LH in urine is also a problem if urinary samples are stored frozen; much of the $\mathrm{LH}$ can be degraded during longterm storage of urine at $-20^{\circ} \mathrm{C}[18,33]$. When interpreting the results of this study, it is important to note that the results are based on subjects referred for investigation of different growth and pubertal disorders. This means that for example the ranges for FMV U-LH and U-FSH concentrations shown (table 2) may not be applicable as reference values for healthy unselected children. Reference values of FMV U-LH and U-FSH [24] and U-LH with the current LHspec assay [13] have been presented previously for healthy children.

We conclude that the measurement of FMV U-LH and the U-LH/U-FSH ratio can be used as a noninvasive method for the biochemical evaluation of pubertal development and its disorders, thus reducing the need for invasive GnRH stimulation tests. Determination of FMV U-LH may also be valuable for monitoring the progression and treatment of precocious puberty as recently suggested by Zung et al. [26].

\section{Acknowledgements}

The authors are grateful to the staff at the GP-GRC, especially Ann-Sofie Petersson and Carina Ankarberg-Lindgren, for both taking care of the patients and performing the laboratory analyses.

Horm Res Paediatr 2016;85:301-308 DOI: $10.1159 / 000440955$
First Morning Voided Urinary LH in the Evaluation of Pubertal Disorders 


\section{References}

$>1$ Apter D, Cacciatore B, Alfthan H, Stenman UH: Serum luteinizing hormone concentrations increase 100-fold in females from 7 years to adulthood, as measured by time-resolved immunofluorometric assay. J Clin Endocrinol Metab 1989;68:53-57.

-2 Bridges NA, Christopher JA, Hindmarsh PC, Brook CG: Sexual precocity: sex incidence and aetiology. Arch Dis Child 1994;70:116118.

3 Kastin AJ, Schally AV, Gual C, Arimura A: Release of $\mathrm{LH}$ and FSH after administration of synthetic LH-releasing hormone. J Clin Endocrinol Metab 1972;34:753-756.

4 Kastin AJ, Schally AV, Schalch DS, Korenman SG, Miller MC 3rd, Gual C, Perez-Pasten E Characterization of the hormonal responses to luteinizing hormone-releasing hormone (LH-RH) in prepubertal and adult subjects. Pediatr Res 1972;6:481-486.

$>5$ Roth JC, Kelch RP, Kaplan SL, Grumbach MM: FSH and $\mathrm{LH}$ response to luteinizing hormone-releasing factor in prepubertal and pubertal children, adult males and patients with hypogonadotropic and hypergonadotropic hypogonadism. J Clin Endocrinol Metab 1972;35:926-930.

6 Garnier PE, Chaussain JL, Binet E, Schlumberger A, Job JC: Effect of synthetic luteinizing hormone-releasing hormone ( $\mathrm{LH}-\mathrm{RH})$ on the release of gonadotrophins in children and adolescents. VI. Relations to age, sex and puberty. Acta Endocrinol (Copenh) 1974;77: 422-434.

$>7$ Pescovitz OH, Hench KD, Barnes KM, Loriaux DL, Cutler GB Jr: Premature thelarche and central precocious puberty: the relationship between clinical presentation and the gonadotropin response to luteinizing hormonereleasing hormone. J Clin Endocrinol Metab 1988;67:474-479.

$\checkmark 8$ Garibaldi LR, Picco P, Magier S, Chevli R, Aceto TJ: Serum luteinizing hormone concentrations, as measured by a sensitive immunoradiometric assay, in children with normal, precocious or delayed pubertal development. J Clin Endocrinol Metab 1991;72:888-898.

-9 Brook CG: Precocious puberty. Clin Endocrinol (Oxf) 1995;42:647-650.

10 Cavallo A, Richards GE, Busey S, Michaels SE: A simplified gonadotrophin-releasing hormone test for precocious puberty. Clin Endocrinol (Oxf) 1995;42:641-646.

$>11$ Kandemir N, Demirbilek H, Ozon ZA, Gonc $\mathrm{N}$, Alikasifoglu A: GnRH stimulation test in precocious puberty: single sample is adequate for diagnosis and dose adjustment. J Clin Res Pediatr Endocrinol 2011;3:12-17.
12 Kim HK, Kee SJ, Seo JY, Yang EM, Chae HJ, Kim CJ: Gonadotropin-releasing hormone stimulation test for precocious puberty. Korean J Lab Med 2011;31:244-249.

13 Demir A, Voutilainen R, Juul A, Dunkel L, Alfthan H, Skakkebaek NE, Stenman UH: Increase in first morning voided urinary luteinizing hormone levels precedes the physical onset of puberty. J Clin Endocrinol Metab 1996;81:2963-2967.

14 Maesaka H, Suwa S, Tachibana K, Kikuchi N: Monthly urinary LH and FSH secretory patterns in normal children and patients with sexual disorders. Pediatr Res 1990;28:405410.

15 Neely E, Wilson D, Lee P, Stene M, Hintz R: Spontaneous serum gonadotropin concentrations in the evaluation of precocious puberty. J Pediatr 1995;127:47-52.

16 Pasternak Y, Friger M, Loewenthal N, Haim A, Hershkovitz E: The utility of basal serum $\mathrm{LH}$ in prediction of central precocious puberty in girls. Eur J Endocrinol 2012;166:295299.

17 Resende EA, Lara BH, Reis JD, Ferreira BP, Pereira GA, Borges MF: Assessment of basal and gonadotropin-releasing hormone-stimulated gonadotropins by immunochemiluminometric and immunofluorometric assays in normal children. J Clin Endocrinol Metab 2007;92:1424-1429.

18 Demir A, Alfthan H, Stenman UH, Voutilainen R: A clinically useful method for detecting gonadotropins in children: assessment of luteinizing hormone and follicle-stimulating hormone from urine as an alternative to serum by ultrasensitive time-resolved immunofluorometric assays. Pediatr Res 1994;36:221226.

19 Maqsood AR, Trueman JA, Whatmore AJ, Westwood M, Price DA, Hall CM, Clayton PE: The relationship between nocturnal urinary leptin and gonadotrophins as children progress towards puberty. Horm Res 2007;68: 225-230.

20 Zachmann M, Prader A, Kind HP, Hafliger H, Budliger H: Testicular volume during adolescence. Cross-sectional and longitudinal studies. Helv Paediatr Acta 1974;29:61-72.

21 Pettersson KS, Soderholm JR: Ultrasensitive two-site immunometric assay of human lutropin by time-resolved fluorometry. Clin Chem 1990;36:1928-1933.

22 Albertsson-Wikland K, Rosberg S, Lannering B, Dunkel L, Selstam G, Norjavaara E: Twenty-four-hour profiles of luteinizing hormone, follicle-stimulating hormone, testosterone, and estradiol levels: a semilongitudinal study throughout puberty in healthy boys. J Clin Endocrinol Metab 1997;82:541-549.
23 Zweig MH, Campbell G: Receiver-operating characteristic (ROC) plots: a fundamental evaluation tool in clinical medicine. Clin Chem 1993;39:561-577.

24 Demir A, Dunkel L, Stenman UH, Voutilainen R: Age-related course of urinary gonadotropins in children. J Clin Endocrinol Metab 1995;80:1457-1460.

25 Witchel S, Baens-Bailon R, Lee P: Treatment of central precocious puberty: comparison of urinary gonadotropin excretion and gonadotropin-releasing hormone $(\mathrm{GnRH})$ stimulation tests in monitoring $\mathrm{GnRH}$ analog therapy. J Clin Endocrinol Metab 1996;81:13531356.

26 Zung A, Burundukov E, Ulman M, Glaser T, Rosenberg M, Chen M, Zadik Z: The diagnostic value of first-voided urinary LH compared with GNRH-stimulated gonadotropins in differentiating slowly progressive from rapidly progressive precocious puberty in girls. Eur J Endocrinol 2014;170:749-758.

27 McNeilly JD, Mason A, Khanna S, Galloway PJ, Ahmed SF: Urinary gonadotrophins: a useful non-invasive marker of activation of the hypothalamic pituitary-gonadal axis. Int J Pediatr Endocrinol 2012;2012:10.

28 Apter D, Butzow TL, Laughlin GA, Yen SS: Gonadotropin-releasing hormone pulse generator activity during pubertal transition in girls: pulsatile and diurnal patterns of circulating gonadotropins. J Clin Endocrinol Metab 1993;76:940-949.

29 Girard J, Hadziselimovic F: Relevance of urinary gonadotrophins. Eur J Pediatr 1987; 146(suppl 2):S18-S20.

30 Maesaka H, Suwa S, Tachibana K, Kikuchi N: Quantitation of urinary gonadotropins in normal children. Pediatr Res 1990;28:401404.

31 Bourguignon JP, Vanderschueren-Lodeweyckx M, Reuter AM, Vrindts-Gevaert Y, Gerard A, Franchimont P: Radioimmunoassays of unextracted gonadotrophins in timed fractions of 24-hour urine: morning increase of gonadotrophin excretion, a circadian pattern in relation to puberty. Horm Res 1980;13: 367-384.

32 Birken S, McChesney R, Yershova O, Gaughan J, Pettersson K, Rechenberg G, Wu CH, Taliadouros G: Patterns of LHbetacf among women in health and disease. Mol Cell Endocrinol 2007;260-262:172-182.

33 Singh GK, Jimenez M, Newman R, Handelsman DJ: Immunoreactive $\mathrm{LH}$ in long-term frozen human urine samples. Drug Test Anal 2013;6:336-341. 